\title{
Modus operandi and affect in Sweden: The Swedish version of the Regulatory Mode Questionnaire
}

\author{
Clara Amato $^{1,2,3}$, Ali Al Nima ${ }^{2,3}$, Marko Mihailovic ${ }^{2,3,4}$, Danilo Garcia ${ }^{\text {Corresp. 2, 3, 5, } 6}$ \\ 1 Engineering Information Department, Pisa University, Pisa, Italy \\ 2 Blekinge Center of Competence, Blekinge County Council, Karlskrona, Sweden \\ 3 Network for Empowerment and Well-Being, Gothenburg, Sweden \\ 4 Department of Psychiatry and Behavioral Sciences, Northwestern University, Chicago, Illinois, United States \\ 5 Department of Psychology, University of Gothenburg, Gothenburg, Sweden \\ 6 Department of Psychology, Lund University, Lund, Sweden \\ Corresponding Author: Danilo Garcia \\ Email address: danilo.garcia@icloud.com
}

Background: The Regulatory Mode Questionnaire (RMQ) is the most used and international well-known instrument for the measurement of individual differences in the two self-regulatory modes: locomotion (i.e., the aspect of self-regulation that is concerned with movement from state to state) and assessment (i.e., the comparative aspect of self-regulation). The aim of the present study was to verify the independence of the two regulatory modes, as postulated by the Regulatory Mode Theory (Kruglanski, Thompson, Higgins, Atash, Pierro, Shah \& Spiegel, 2000), and the psychometric properties of the RMQ in the Swedish context. Furthermore, we investigated the relationship between regulatory modes (locomotion and assessment) and affective well-being (i.e., positive affect and negative affect).

Method: A total of 655 university and high school students in the West of Sweden (males $=408$ females $=242$, and 5 participants who didn't report their gender; age $_{\text {mean }}=21.93 \pm 6.51$ ) responded to the RMQ and the Positive Affect Negative Affect Schedule. We conducted two confirmatory factor analyses using structural equation modeling (SEM). A third SEM was conducted to test the relationship between locomotion and assessment to positive affect and negative affect.

Results: The first analyses confirmed the unidimensional factor structure of locomotion and assessment and both scales showed good reliability. The assessment scale, however, was modified by dropping item 10 ("I don't spend much time thinking about ways others could improve themselves.") because it showed low loading $(.07, p=.115)$. Furthermore, the effect of locomotion on positive affect was stronger than the effect of assessment on positive affect $(Z=-15.16, p<.001)$, while the effect of assessment on negative affect was stronger than the effect of locomotion on negative affect $(Z=10.73, p<.001)$.

Conclusion: The factor structure of the Swedish version of the RMQ is, as Regulatory Mode Theory suggests, unidimensional and it showed good reliability. The scales discriminated between the two affective well-being dimensions. We suggest that the Swedish version of the RMQ, with only minor modifications, is a useful instrument to tap individual differences in locomotion and assessment. Hence, the present study contributes to the validation of the RMQ in the Swedish culture and adds support to the theoretical framework of self-regulatory mode. 
1 Under editorial evaluation in PeerJ

2 Please do not quote without permission

3

4

5

6

7

8

9

10

11

12

13

14

15

16

17

18

19

20

21

22

23
Modus Operandi and Affect in Sweden: The Swedish Version of the Regulatory Mode Questionnaire Clara Amato ${ }^{1,2,3}$, Ali Al Nima ${ }^{2,3}$, Marko Mihailovic 2, 3, 4, Danilo Garcia 2, 3, 5, 6* ${ }^{1}$ Engineering Information Department, Pisa University, Pisa, Italy ${ }^{2}$ Blekinge Center for Competence, Blekinge County Council, Karlskrona, Sweden ${ }^{3}$ Network for Empowerment and Well-Being, Sweden

${ }^{4}$ Department of Psychiatry and Behavioral Sciences, Northwestern University, Chicago, Illinois, USA

${ }^{5}$ Department of Psychology, University of Gothenburg, Gothenburg, Sweden ${ }^{5}$ Department of ${ }^{6}$ Psychology, Lund University, Lund, Sweden 


\section{Abstract}

27 Background: The Regulatory Mode Questionnaire (RMQ) is the most used and international well-known instrument for the measurement of individual differences in the two self-regulatory modes: locomotion (i.e., the aspect of self-regulation that is concerned with movement from state to state) and assessment (i.e., the comparative aspect of self-regulation). The aim of the present study was to verify the independence of the two regulatory modes, as postulated by the Regulatory Mode Theory (Kruglanski, Thompson, Higgins, Atash, Pierro, Shah \& Spiegel, 2000), and the psychometric properties of the RMQ in the Swedish context. Furthermore, we investigated the relationship between regulatory modes (locomotion and assessment) and affective well-being (i.e., positive affect and negative affect).

Method: A total of 655 university and high school students in the West of Sweden (males $=408$ females $=242$, and 5 participants who didn't report their gender; age $_{\text {mean }}=21.93 \pm 6.51$ ) responded to the RMQ and the Positive Affect Negative Affect Schedule. We conducted two confirmatory factor analyses using structural equation modeling (SEM). A third SEM was conducted to test the relationship between locomotion and assessment to positive affect and negative affect.

Results: The first analyses confirmed the unidimensional factor structure of locomotion and assessment and both scales showed good reliability. The assessment scale, however, was modified by dropping item 10 ("I don't spend much time thinking about ways others could improve themselves.") because it showed low loading $(.07, p=.115)$. Furthermore, the effect of locomotion on positive affect was stronger than the effect of assessment on positive affect $(Z=$ $15.16, p<.001)$, while the effect of assessment on negative affect was stronger than the effect of locomotion on negative affect $(Z=10.73, p<.001)$.

Conclusion: The factor structure of the Swedish version of the RMQ is, as Regulatory Mode Theory suggests, unidimensional and it showed good reliability. The scales discriminated between the two affective well-being dimensions. We suggest that the Swedish version of the RMQ, with only minor modifications, is a useful instrument to tap individual differences in locomotion and assessment. Hence, the present study contributes to the validation of the RMQ in 
54 the Swedish culture and adds support to the theoretical framework of self-regulatory mode.

55

56

57

58

59

60

61

62

63

64

65

66

67

\section{Introduction}

The Regulatory Mode Questionnaire (RMQ; Kruglanski, Thompson, Higgins, Atash, Pierro, Shah \& Spiegel, 2000) measures individual differences in the way people prefer to operate when striving to reach a goal. Specifically, the RMQ measures how individuals differ in their tendency to move from state to state towards a goal (locomotion) and in their tendency to compare different alternatives, such as, the value of different goals or the different means to reach a chosen goal (assessment). Structurally, the RMQ is constituted by two scales that tap individual differences in locomotion and assessment ${ }^{1}$. So far, the RMQ has been translated into several languages (e.g., French, Italian, Spanish, Japanese, Hebrew, Hindu, and Korean), including Swedish (see Table 1; Jimmefors, Garcia, Rosenberg, Mousavi, Adrianson \& Archer, 2014; Garcia, Jimmefors, Mousavi, Adrianson, Rosenberg \& Archer, 2015; Garcia \& Archer, 2016; Garcia \& Lindskär, 2016; Garcia, Roseneberg, Lindskär, Amato \& Nima, 2017). A few studies, have demonstrated the unidimensionality, the internal consistency, and the temporal stability as well as the convergent and discriminant validity of each of the two scales in the RMQ (Kruglanski, Thompson, Higgins, Atash, Pierro, Shah, \& Spiegel, 2000). However, with exception of the Italian and the original English version, the structure and psychometric properties of these versions of the RMQ have not yet been investigated. In the present study, we test the unidimensionality and reliability of the Swedish version of the RMQ scales (locomotion

\footnotetext{
${ }^{1}$ Although the RMQ also contains a lie scale, consisting of 6 items (see white cells in Table 1), this scale is often not used in most research and some studies have also applied only one of the scales (e.g., locomotion; Pierro, Giacomantonio, Pica, Kruglanski \& Higgins, 2013).
} 
76 and assessment). Furthermore, we also investigate the relationship between regulatory modes

77 and affective well-being (i.e., positive affect and negative affect) in the Swedish sample at hand.

78 Importantly, positive affect and negative affect are not only indicators or markers of well-being

79 (Diener, 1984), these two affectivity dimensions are two distinctive factors that reflect stable

80 emotional-temperamental dispositions and form together an adaptive complex signal sensitivity

81 system (e.g., Watson \& Clark, 1994; Watson, Clark, \& Tellegen; 1988; Tellegen, 1993; Garcia,

82 2011, 2017a). In the following sections, we will introduce Regulatory Mode Theory (Kruglanski,

83 Thompson, Higgins, Atash, Pierro, Shah \& Spiegel, 2000), we will provide an overview of the

84 wide range of use of the RMQ, and we will develop the expected associations between the

85 regulatory modes (locomotion and assessment) and the affective well-being dimensions (i.e.,

86 positive and negative affect).

Table 1 should be here

\section{Regulatory Mode Theory: Locomotion and Assessment Orientations}

89 In the classic theory of control (Carver \& Scheier, 1990), assessment and locomotion are

90 functionally interdependent parts of a single self-regulatory process. In the first step, through the

91 assessment function, an individual compares the different mental goal representations and

92 chooses the favorite one, then he/she compares the current state with the desired end-state. In the

93 second step, through the locomotion function, the individual tries to reduce the current-end states

94 discrepancy by starting and maintaining movement toward the target goal. Conversely, in the

95 frame of Regulatory Mode Theory (Higgins, Kruglanski \& Pierro, 2003), locomotion and

96 assessment are independent functions, which can receive different emphasis. In this context,

97 locomotion is the aspect of self-regulation concerned with "movement from state to state and

98 with committing the psychological resources that will initiate and maintain goal-related 
99 movement in a straightforward and direct manner, without undue distractions or delays"

100 (Kruglanski, Thompson, Higgins, Atash, Pierro, Shah \& Spiegel, 2000, p. 794) and assessment is

101 "the comparative aspect of self-regulation concerned with critically evaluating entities or states,

102 such as goals or means, in relation to alternatives in order to judge relative quality" (Kruglanski,

103 Thompson, Higgins, Atash, Pierro, Shah \& Spiegel, 2000, p. 794).

104 There are two important assumptions in Regulatory Mode Theory: 1) temperament and 105 socialization lead individuals to develop different degrees of concern with movement or progress 106 (i.e., emphasizing locomotion) and different degrees of concern for standards and for critically 107 evaluating alternatives (i.e., emphasizing assessment) and 2) the reasons for preferring 108 locomotion or assessment are unrelated (Kruglanski, Thompson, Higgins, Atash, Pierro, Shah \& 109 Spiegel, 2000). In other words, locomotion and assessment are independent and orthogonal 110 biopsychosocial modes of operation, thus, some individuals can be high on one mode and low on

111 the other mode, low on both modes, or high on both modes (cf. Garcia \& Lindskär, 2016). The 112 RMQ is indeed an instrument that helps to measure the chronic preference for one regulatory 113 mode orientation over the other.

\section{Applications of the RMQ}

115 Previous studies have shown the high practical relevance and the wide potential applicability of 116 the RMQ. Since its development, several studies have shown that the two regulatory modes are 117 related with many important aspects, ranging from organizational behavior (e.g., preference for 118 leadership style; Benjamin \& Flynn, 2006; time management; Amato, Pierro, Chirumbolo \& 119 Pica, 2014), to entrepreneurial aptitude (Amato, Baron, Barbieri, Bélanger \& Pierro, 2017), to 120 cognition (e.g., cognitive biases, counterfactual thinking; Pierro, Leder, Mannetti, Higgins, 121 Kruglanski, \& Aiello, 2008), and economic decision-making (e.g., inter-temporal choices; 
122 Mannetti, Leder, Insalata, Pierro, Higgins, \& Kruglanski, 2009). Particularly relevant to the

123 present study, is the strong link between self-regulation and both health and well-being.

124 Specifically, there is evidence that a prevalence of locomotion orientation is positively related to

125 affective well-being (i.e., frequent experience of positive affect and infrequent experience of

126 negative affect), while a prevalence of assessment orientation is associated with maladaptive

127 psychological functioning and even psychopathological symptoms (Garcia, Nima, Lindskär,

128 Jimefors, Archer, \& MacDonald, 2016). For instance, locomotion is both indirectly and directly

129 positively related to affective well-being. For example, people who are high in locomotion do not

130 engage in social comparison and have therefore a tendency to be less materialistic, which in turn

131 leads them to experience less negative affect (Giacomantonio, Mannetti, \& Pierro, 2013). Indeed,

132 engaging in social comparison and self-evaluation, something a person does when in assessment

133 mode, leads to materialistic thinking, which in turn leads to high levels of negative affect

134 (Giacomantonio, Mannetti, Pierro, 2013). That being said, affective well-being is more that the

135 absence of negative emotions (cf. Cloninger, 2004). In this context, people who are high in

136 locomotion report having a sense of life purpose and this lead them to be more satisfied with

137 their life (Vazeou-Nieuwenhuis, Orehek, \& Scheier, 2017). In addition, locomotion is directly

138 related to higher levels of vitality (Kruglanski, Thompson, Higgins, Atash, Pierro, Shah \&

139 Spiegel, 2000), higher levels of optimism (Kruglanski, Thompson, Higgins, Atash, Pierro, Shah

140 \& Spiegel, 2000), happiness (Smith, Haynes, Lazarus \& Pope, 1993) and last but not the least,

141 positive affect (Kruglanski, Thompson, Higgins, Atash, Pierro, Shah, \& Spiegel, 2000; Garcia,

142 Jimmefors, Mousavi, Adrianson, Rosenberg, \& Archer, 2015; Garcia, Nima, Lindskär, Jimefors,

143 Archer, \& MacDonald, 2016). Individuals with a high assessment orientation, on the other hand,

144 are more likely to present depressive symptoms (Hong, Tan \& Chang, 2004), they are also more 
145 susceptible to suffer from borderline disorder (Bornovalova, Fishman, Strong, Kruglanski \&

146 Lejuez, 2008) and obsesive-compulsive disorder (Shalev \& Sulkowski, 2009), and report high

147 levels of negative affect (Kruglanski, Thompson, Higgins, Atash, Pierro, Shah \& Spiegel, 2000;

148 Garcia, Jimmefors, Mousavi, Adrianson, Rosenberg \& Archer, 2015; Garcia, Nima, Lindskär,

149 Jimefors, Archer \& MacDonald, 2016),

150 The Present Study

151 In the present study, based on Regulatory Mode Theory we test the unidimensionality of the

152 Swedish version of the RMQ scales (locomotion and assessment). We also test the reliability of

153 the Swedish RMQ and the predictive validity of the regulatory mode scales by investigating the

154 relationship between regulatory modes (locomotion and assessment) and affective well-being

155 (positive and negative affect). The affectivity dimensions were found appropriate, to test the

156 RMQ scales' predictive validity, for different reasons.

157 First of all, the affectivity dimension range from pleasant/unpleasant engagement (for 158 example: enthusiastic and active for positive affect, anger and fear for negative affect), to

159 unpleasant/pleasant disengagement (for example: sad and bored for positive affect, calm and 160 serene for negative affect) (Watson, Clark \& Tellegen, 1988; Watson \& Clark, 1994). Thus, as

161 locomotion and assessment (Kruglanski, Thompson, Higgins, Atash, Pierro, Shah \& Spiegel,

162 2000), positive affect and negative affect are best conceptualized as two independent orthogonal

163 dimensions that are part of a complex adaptive system and not as ends of one single dimension

164 (Garcia, 2011, 2017a). These two affectivity dimensions reflect approaching behavior (positive 165 affect) and avoidant behavior (negative affect) (Garcia, 2011, 2017a). Thus, we expected

166 locomotion to predict positive affect or approaching behavior and assessment to predict negative 167 affect or avoidant behavior (cf. with Kruglanski, Thompson, Higgins, Atash, Pierro, Shah \& 
168 Spiegel, 2000, who also suggested a positive correlation between locomotion and positive affect

169 because locomotion or forward movement contributes to a sense of progress and a positive 170 correlation between assessment and negative affect because high assessment involves ruminating

171 self-evaluation that may highlight the discrepancies between one's actual self and a desired self).

172 Secondly, according to Regulatory Mode theory, temperament and socialization lead

173 individuals to develop different degrees of locomotion and assessment. Indeed, Kruglanski and 174 colleagues (2000) found a positive correlation between locomotion and extraversion $(r=.38 ; p<$ $175.001)$, a negative correlation between locomotion and neuroticism $(r=-.20 ; p<.001)$, a positive 176 correlation between assessment and neuroticism $(r=.41 ; p<.001)$, and a negative correlation

177 between assessment and extraversion ( $r=-.03$; nonsignificant $)$. Notably, positive and negative 178 affect are almost identical with these personality traits (i.e., extraversion and neuroticism, 179 respectively) (Larsen \& Ketelaar, 1991; see also Garcia, Adrianson, Archer \& Rosenberg, 2015; 180 Garcia, Ghiabi, Rosenberg, Nima \& Archer, 2015; Rapp Ricciardi, Åkerman, Eerikäinen, 181 Ambjörnsson, Andersson Arntén, Archer \& Garcia, 2014; Garcia \& Moradi, 2013; Garcia, 2012;

182 Garcia, Rosenberg, Erlandsson \& Siddiqui, 2010). In addition, compared to extraversion and 183 neuroticism, the two affectivity dimensions involve more mood and social traits (Gunderson, 184 Triebwasser, Phillips, \& Sullivan, 1999). Therefore, these affectivity dimension are not only seen 185 as temperamental dispositions or signal sensitivity systems, but also as being complementary to 186 extraversion and neuroticism (Tellegen, 1993). We argue that this supports our expectation of a 187 positive relationship between locomotion and positive affect and between assessment and 188 negative affect. In addition, this suggests a negative or non-significant relationship between 189 locomotion and negative affect and between assessment and positive affect. Hence, we expected 190 a stronger relationship between locomotion and positive affect than between assessment and 
191 positive affect. Conversely, we expected a stronger relationship between assessment and

192 negative affect than between locomotion and negative affect.

193

194

195

196

197

198

199

200

201

202

203

204

205

206

207

208

209

210

211

212

213

\section{Materials and Methods}

\section{Ethical statement}

After consulting with the Network for Empowerment and Well-Being's Review Board we arrived at the conclusion that the design of the present study (e.g., all participants' data were anonymous and will not be used for commercial or other non-scientific purposes) required only informed consent from the participants.

\section{Participants and procedure}

A total of 655 students (357 university students and 298 high school students) in the West of Sweden $\left(\right.$ males $=408$ females $=242$, and 5 participants who didn't report their gender, age ${ }_{\text {mean }}=$ $21.93 \pm 6.51)$ participated in the study. All participants were informed that taking part of the study was voluntary and anonymous. They were presented with paper-pencil Swedish versions of the RMQ and the Positive Affect Negative Affect Schedule.

\section{Measures}

Self-regulation. The Swedish version (Garcia, Jimmefors, Mousavi, Adrianson, Rosenberg, \& Archer, 2015; Garcia, Rosenberg, Lindskär, Amato, \& Nima, 2017) of the RMQ (Kruglanski, Thompson, Higgins, Atash, Pierro, Shah, \& Spiegel, 2000) was used to assess self-regulatory mode/orientations. The test consists of 30 items measured on a 6 point likert scale (from $1=$ strongly disagree to $6=$ strongly agree); 12 items measuring assessment (e.g., "I spend a great deal of time taking inventory of my positive and negative characteristics", "I am a critical person"), 12 items measuring locomotion (“I am a doer', "'When I get started on something, I usually persevere until I finish it"), and six constituting a lie scale that was not analyzed in the 
214 present study (see Table 1).

215

Affect. The Positive Affect and Negative Affect Schedule (Watson, Clark \& Tellegen, 216 1988) assesses the affective component of subjective well-being by requiring participants to rate

217 to what extent ( 1 = very slightly, 5 = extremely) during the last few weeks they have experienced

21810 positive (e.g., strong, proud) and interested and 10 negative (e.g., afraid, ashamed, and 219 nervous) affective states. The Swedish version has been used in previous studies with good 220 psychometric properties (e.g., Schütz, Archer \& Garcia, 2013).

\section{Preliminary descriptive analyses}

222 We conducted Preliminary analyses to test some statistical issues, such as the presence of 223 outliers and collinearity between variables. We first standardized the scores of each variable and 224 tested if any cases had larger standardized scores than \pm 3.29 , as recommended by Tabachnick 225 and Fidell (2007). The analysis detected no cases of univariate outliers. The variables had 226 skewness between -.10 to .64 and kurtosis between .70 and .12 , thus, indicating that the data did 227 not violate the assumption of normality (see, Barker, 2007, p. 341; Tabachnick \& Fidell, 2007, 228 p.80). Moreover, we examined the distributions of the items and linearity by scatter plots. The 229 results showed the absence of any signs of violation of normality and linearity assumptions. 230 Finally, all the significant correlations among the variables were not so high as to threaten 231 statistical multicollinearity and singularity. Indeed, the correlation coefficients range between .08 232 to .53 , thus not constituting a cause for multicollianiarity and singularity issues (see, Tabachnick $233 \&$ Fidell, 2007, p.88). Table 2 show the correlations between variables in the presents study, 234 along Cronbach's alphas and both means and standard deviations for each variable.

235 236
Table 2 should be here

Results 
237 Based on Regulatory Mode Theory we first tested the unidimensionality of the Swedish version

238 of the RMQ scales (locomotion and assessment) using two separate confirmatory factor analyses

239 through structural equation modeling (SEM), one for locomotion and one for assessment. We

240 used separate analyses since locomotion and assessment are two independent unrelated modes of

241 operation (e.g., Kruglanski, Thompson, Higgins, Atash, Pierro, Shah, \& Spiegel, 2000).

\section{Locomotion}

243 The first confirmatory analysis was conducted using the 12 items to estimate locomotion as one

244 factor. The analysis showed that chi-square value was significant $\left(C h i^{2}=268.79, d f=54, p<\right.$ $245.001)$, the goodness of fit index was .93 and the root mean square error of approximation for the 246 default model was .08. The chi-square statistic is heavily influenced by sample size (Kline, 247 2010), with larger samples (in this study $N=650$ ) leading to larger value and therefore, a larger

248 likelihood of being significant. However, other values (the goodness of fit index and the root 249 mean square error of approximation) indicated that the hypothesized model fits the data well.

250 All the regression weights/loadings between the factor (i.e., locomotion) and its 12 items were 251 significant at $p<.001$ (ranging from .32 to .72) with the exception of two items that had low 252 loadings (.29 for the reversed item 13: "When I finish one project, I often wait awhile before 253 getting started on a new one." and .15 for item 16: "When I decide to do something, I can't wait 254 to get started.") which were also significant at $p<.001$ (see Figure 1 and Table 3). Nevertheless, 255 the results mirror those in the original article (Kruglanski, Thompson, Higgins, Atash, Pierro, 256 Shah \& Spiegel, 2000) in which the fit of the one-factor model for both the locomotion and 257 assessment scales were higher than .90 for goodness of fit index, RMRs around .10, and the 258 overall alpha for locomotion was .82 . 


\section{Assessment}

261 The second confirmatory analysis was conducted using the 12 items to estimate assessment as

262 one factor. The analysis showed that chi-square value was significant $\left(C h i^{2}=362.20, d f=54, p\right.$

$263<.001)$, the goodness of fit index was .91 and the root mean square error of approximation for

264 the default model was .09. However, based on other important statistical indexes, such as the

265 goodness of fit index and the root mean square error of approximation, we assumed that the

266 model fits the data well. All the regression weights/loadings between the factor (i.e., assessment)

267 and its items were significant at $p<.001$ (ranging from .26 to .66) with the exception of reversed

268 item 10 (“I don't spend much time thinking about ways others could improve themselves.")

269 which had low loading $.07(n s, p=.115)$ (see Figure 2). Hence, item 10 was removed from the

270 analyses. After this, the analysis showed that chi-square value was significant $\left(C h i^{2}=336.88, d f\right.$

$271=44, p<.001)$, the goodness of fit index was .91 and the root mean square error of

272 approximation for the model was .10 (see Figure 3 and Table 3). All the regression

273 weights/loadings between the factor (i.e., assessment) and its 11 items were significant at $p<$

274.001 with ranging from .26 to .66 . Thus, the model with just 11 items fits the data well.

275

276

277

278

279

280

281

282
Figure 2 should be here

Figure 3 should be here

Table 3 should be here

\section{Locomotion, Assessment, and affective well-being}

In the third SEM, we conducted a path analysis using locomotion (comprising 12 items) and assessment (comprising 11 items) as the independent variables and positive affect and negative affect as the dependent variables. The analysis showed that chi-square value was significant $\left(\mathrm{Chi}^{2}=27.85, d f=1, p<.001\right)$. However, as for the other two models previously presented, the 
283 goodness of fit index (.98), comparative fit index (.93), incremental fit index (.93), and normed fit

284 index (.93) indicated that the hypothesized model fits the data well. All the regression weights

285 between the independent variables (locomotion, assessment) and the dependent variables

286 (positive affect and negative affect) were significant at $p<.001$. Standardized parameter

287 estimates of correlation and direct effects appear in Figure 4 and both standardized and 288 unstandardized coefficients are listed in Table 4.

289 Additionally, we tested assessment and locomotion's equalities of regression paths by 290 comparing the regression weights between locomotion-positive affect to assessment-postive 291 affect and between locomotion-negative affect and assessment-negative affect. The result 292 showed that the effect of locomotion on positive affect was stronger than the effect of 293 assessment on positive affect (Critical Ratios for Differences between Parameters/Z statistic = $29415.16, p<.001)$, while the effect of assessment on negative affect was stronger than the effect of 295 locomotion on negative affect (Critical Ratios for Differences between Parameters/Z statistic= 296 10.73, $p<.001)$. See Table 3.

297

298

299

300

301

302 303 304 305

$\underline{\text { Figure } 4 \text { should be here }}$

Table 4 should be here

\section{Discussion}

Over 10 years of research on self-regulation show that individual differences in regulatory mode tendencies affect many aspects of human behavior, and, consequently, health and well-being. The aim of the present study was twofold: 1) to test the applicability of the RMQ in the Swedish context by examining the unidimensionality of the two RMQ scales (i.e., locomotion scale and assessment scale) and their reliability; 2) to test the predictive and discriminant validity of the locomotion and assessment scales by investigating the relationship between the two regulatory 
306 modes (i.e., locomotion and assessment) and the affective well-being dimensions (i.e., positive

307 affect and negative affect). First of all, as far as we know, the theorized unidemensionallity of the

308 two modes of regulation has been empirically tested only in the English and the Italian versions

309 of the RMQ (Kruglanski, Thompson, Higgins, Atash, Pierro, Shah \& Spiegel, 2000). Thereby the

310 importance of providing further support to the validity of RMQ across different cultures.

311 Secondly, to our understanding ${ }^{2}$, the regulatory modes are theorized as biopsychosocial in nature

312 (i.e., influenced by temperament, psychological resources, and socialization), thus, positive

313 affect and negative affect were found appropriate for predictive and discriminant validity

314 analyses. After all, besides being markers of well-being, positive and negative affect are

315 independent and stable temperamental dispositions that involve more mood and social traits than

316 extraversion and neuroticism (e.g., Watson \& Clark, 1994; Watson, Clark, \& Tellegen; 1988;

317 Tellegen, 1993; Garcia, 2011, 2017a).

318 At a general level, the results obtained here show that both locomotion and assessment

319 have a unidimensional factor structure, thus confirming the findings of previous research

320 conducted with other samples (Kruglanski, Thompson, Higgins, Atash, Pierro, Shah, \& Spiegel,

321 2000). The Swedish RMQ revealed to also have good indexes of reliability for both scales. That

322 being said, the locomotion reversed item 13 ("When I finish one project, I often wait awhile

323 before getting started on a new one.") and item 16 ("When I decide to do something, I can't wait

324 to get started.") showed significant but relatively low loadings (.29 and .15 , respectively). In

${ }^{2}$ To the best of our knowledge this is the first scientific article referring to the regulatory modes as a biopsychosocial complex adaptive system (cf. Garcia, 2017a). Nevertheless, others (Garcia \& Lindskär, 2016) have assumed this complex interaction by suggesting regulatory mode profiles: assessor (i.e. high in assessment/low in locomotion), low regulator (i.e. low assessment/low locomotion), high regulator (i.e. high assessment/high locomotion), and locomotor (i.e. low assessment/high locomotion). 
325 addition, the assessment reversed item 10 ("I don't spend much time thinking about ways others 326 could improve themselves.") showed low loading $(.07, p=.115)$ and was discarded from the final

327 analyses. With regard to the reversed items in both scales (items 10 and 13), despite the potential

328 benefits (e.g., minimizing the problems of inattention and acquiescence), one of the problems

329 derived from using reversed items is that they indeed produce unexpected factor structures (e.g.,

330 Netemeyer, Bearden, \& Sharma 2003) and miscomprehension (Swain, Weathers, \& Niedrich

331 2008). These problems are actually more marked among subcultural groups, such as, ethnic and

332 racial minorities (Steekamp \& Burgees, 2002). In fact, these problems seem to be more

333 pronounced when scales are used in cultures that differ in values, customs, and language from

334 the original culture in which the scale was developed (cf. Wong, Rindfleisch \& Burroughs 2003).

335 For instance, Sweden has the fourth place and Italy, one of the few countries in which the RMQ

336 has been validated, the fiftieth place in the 2016 report from the World Economic Forum's

337 Global Gender Gap (see https://www.weforum.org/reports/the-global-gender-gap-report-2016).

338 Additionally, Sweden is an individualistic culture (Kjell, Nima, Sikström, Archer, \& Garcia,

339 2013) and widely known for Jantelagen ${ }^{3}$, suggesting that Swedes have a tendency to not show

340 off by presenting themselves as better than someone else (Fayolle, Kyro, \& Ulijn, 2005).

341 Probably explaining why, a question with a statement such as: "I don't spend much time thinking

342 about ways others could improve themselves." (assessment reversed item 10), is problematic in

\footnotetext{
${ }^{3} \mathrm{~A}$ description of a pattern of group behavior towards individuals within Nordic countries that negatively portrays and criticizes individual success and achievement as unworthy and inappropriate. Used generally in colloquial speech in the Nordic countries as a sociological term to describe a condescending attitude towards individuality and success, the term refers to a mentality that de-emphasizes individual effort and places all emphasis on the collective, while simultaneously denigrating those who try to stand out as individual achievers. Retrieved from https://en.wikipedia.org/wiki/Law of Jante\#cite note-3.
} 
343 the Swedish context. One way or another, we strongly recommend the replication of the present

344 study in other Swedish samples before totally removing this specific item from future studies.

$345 \quad$ Furthermore, locomotion predicts high (vs. low) positive affect, while assessment predicts

346 high (vs. low) negative affect. Locomotion orientation is by definition the aspect of self-

347 regulation concerned with maintaining goal-directed progress in a straightforward manner,

348 without undue distractions or delays (Kruglanski, Thompson, Higgins, Atash, Pierro, Shah, \&

349 Spiegel, 2000); individuals with high locomotion orientation have a high behavioral activation

350 system (Higgins, Kruglanski, \& Pierro, 2003), they engage in goal pursuit promptly and exhibit a

351 stronger task orientation (i.e., the tendency to attend to an activity and persist conscientiously

352 until completion). Furthermore, individuals high in locomotion manage their time more

353 efficiently and, consequently, they feel to have control over the time (Amato, Pierro,

354 Chirumbolo, \& Pica, 2014), which is a very important resource for them (Amato, Baldner,

355 Pierro, \& Kruglanski, 2017). These features result in a sense of self-regulatory competence and 356 self-maintenance (i.e., maintaining control over attention) among individuals high in locomotion.

357 Indeed, individuals high on positive effect show these features as well (Cloninger \& Garcia, 358 2015). Within this picture, the results of the present study about the relationship between 359 locomotion and affective well-being, are completely consistent with previous findings describing 360 individuals with high locomotion orientation as active people, full of energy, with full 361 concentration (i.e., high Positive affect; Watson, Clark \& Tellegen, 1988). At the same time, the 362 tendency to move forward, typical of the locomotion orientation, lead individuals high in 363 locomotion to pass away from negative feelings (e.g., guilt; regret; Pierro, Leder, Mannetti, 364 Higgins, Kruglanski, \& Aiello, 2008; Pierro, Pica, Kruglanski, \& Higgins, 2014) and to not stay 365 engaged with unpleasant mode states (i.e., low Negative affect, Watson, Clark, \& Tellegen, 
366 1988). On the other hand, the tendency to make social comparisons and to engage frequently in

367 self-evaluation, typical of the assessment orientation, may lead individuals high in assessment to

368 struggle with a large discrepancy perceived between current state and external standards, and

369 between real attainments and the ideal end-states. This determine a subjective distress

370 characterized by the presence of several aversive mood states among individuals high in

371 assessment (i.e., high negative affect). These findings confirm the key role of regulatory mode in

372 affective well-being (Garcia \& Lindskär, 2016) and confirm the discriminant and predictive

373 validity of the RMQ in the Swedish context.

\section{Limitations and suggestions for future research}

375 To provide a valid instrument to use in the Swedish context is useful at the theoretical, research,

376 and practical levels. At a theoretical level, the results presented here support the notion of two

377 independent constructs of self-regulation that lead to different approach (positive affect) and

378 prevention (negative affect) behaviors (cf. Garcia, 2011, 2017a). That being said, at this point a

379 fully biopsychosocial theory of self-regulation needs to be developed using holistic models, such

380 as, Cloninger's ternary model of human personality (Cloninger, 2004). This model disentangles

381 personality in biological (harm avoidance, novelty seeking, reward dependence, and persistence),

382 psychological (self-directedness and cooperativeness), and social (self-transcendence) aspects of

383 personality (Cloninger, 2004; Garcia, Cloninger, Lester \& Cloninger, 2017; Garcia, Lester,

384 Cloninger \& Cloninger, 2017ab; Garcia, Rosenberg, Lester, Cloninger \& Cloninger, 2017).

385 Hence, we suggest that future research should find the Cloninger personality model useful to test

386 if self-regulatory mode theory is biopsychosocial in nature. As far as we understand the theory,

387 self-regulation should be biopsychosocial; but no other work has addressed the concept

388 holistically. At the research level, the Swedish RMQ could be used in the fields of motivation, 
389 health, personality, and organizational settings.

390 At the practical level, the RMQ could be a useful tool of evaluation of current social

391 challenges in Sweden. For instance, Swedish students report grades that are among the lowest of

392 the other 32 OECD countries (PISA, Sverigesradio, 2013; SNAE, 2009; 2012) along

393 deteriorations in psychological health (Fleming, Clark, Denny, Bullen, Crengle, Peiris-John,

394 Robinson, Rossen, Sheridan \& Lucassen, 2013; Ghofranipour, Saffari, Mahmoudi \& Montazeri, 395 2013). At the same time, many Swedish high schools decrease the number of physical education 396 hours available for their students (Sverigesradio, 2013) - a type of activity that is well397 documented for positive effects on psychological health and well-being among adolescents and 398 young adults (e.g., Archer \& Garcia, 2014). Interestingly, in a sample of Swedish adolescents, 399 locomotion predicted frequently exercising, which in turn predicted higher grades, while 400 assessment predicted higher grades but also lower levels of well-being (Garcia, Jimmefors, 401 Mousavi, Adrianson, Rosenberg \& Archer, 2015). These findings suggest that interventions need 402 to be holistic or biopsychosocial, that is, targeting all aspects of self-regulatory mode in order to 403 target both academic achievement and well-being (cf. Garcia, Drugge, Blixt Samuelsson, Storm, 404 Archer, \& Cloninger, 2016). We suggest that the RMQ could be used as a tool in this endeavor. 405 In addition, since regulatory mode can be situationally induced (Avnet \& Higgins, 2003) and 406 situations may influence the preference of one mode over the other (Kruglanski, Orehek, 407 Higgins, Pierro \& Shalev, 2010), then, educators and other practitioners might design person408 centered interventions that enhance or promote locomotion orientation through movement or 409 exercise.

410 In spite of its theoretical and practical relevance, the present study has some limitations.

411 We didn't include other measures of individual differences (e.g., Big Five) in order to test the 
412 incremental validity of regulatory mode in the prediction of affective well-being. Even if 413 previous studies have shown that the relationship between regulatory mode and, for example, 414 psychological vitality or energy, remain unchanged while controlling for the Big Five personality 415 factors (Kruglanski, Thompson, Higgins, Atash, Pierro, Shah \& Spiegel, 2000), it would be 416 useful to address this issue in cross-cultural studies (cf. Delle Fave \& Bassi, 2009, who suggest 417 cross-cultural studies as important to disentangle happiness and related constructs). It is also 418 worth to notice that our sample was unbalanced with respect to gender. The higher presence of 419 males, compared to females, could lead to a selection bias. Despite that earlier studies, using 420 samples from other cultures, have not indicated any significant gender differences (Kruglanski et 421 al., 2000), it could be interesting to investigate the presence/absence of this difference in a 422 Swedish sample and its effect on the factor structure of the RMQ. After all, gender differences 423 seem to depend on the level of egalitarianism within the culture-although counter-intuitive, 424 gender differences in, for example, personality traits, self-esteem, subjective well-being, and 425 depression are larger in relatively high gender egalitarian cultures, such as Sweden (Schmitt, 426 Long, McPhearson, O’Brien, Remmert \& Shah, 2016). Another concern is that our sample only 427 comprised high school and university students. Hence, further studies should include a more 428 heterogeneous sample to address differences in, for example, gender, education level and also 429 age. Moreover, although most of the studies using the RMQ disregard of the lie scale, as we did, 430 and some have also applied only one of the scales (e.g., locomotion; Pierro, Giacomantonio, 431 Pica, Kruglanski \& Higgins, 2013), it might be useful to consider the presence of social 432 desirability in future studies. Also, longitudinal designs would provide insights on the Swedish 433 RMQ's test-retest validity and perhaps also a better understanding of the causal relationships 434 between regulatory mode and affectivity. 
Finally, we urge person-oriented approaches for the investigation and development of

436 Regulatory Mode Theory. Especially since peoples' tendency to prefer either locomotion and

437 assessment is probably influenced by unrelated biological (e.g., temperament), psychological and

438 social resources and conditions (Kruglanski, Thompson, Higgins, Atash, Pierro, Shah \& Spiegel,

439 2000). In other words, locomotion and assessment are independent and orthogonal

440 biopsychosocial modes of operation, thus, some individuals can be high on one mode and low on

441 the other mode, low on both modes, or high on both modes (cf. Garcia \& Lindskär, 2016).

442 Person-oriented statistical approaches are methods that focus on internal patterns, in contrast to

443 variable-oriented approaches which focus on individual differences (Lundh, 2015). For instance,

444 from a person-oriented framework these two modes of operation (locomotion and assessment)

445 within the individual can be seen as interwoven components with whole-system properties

446 (Bergman \& Wångby, 2014). The outlook of the individual as a whole-system unit is then best

447 studied by analyzing patterns of information (Bergman \& Wångby, 2014; Bergman, Magnusson

448 El-Khouri, 2003; Bergman \& Wångby, 2014; Bergman \& Magnusson, 1997; see also Cloninger,

449 Svrakic \& Svrakic, 1997, who explain nonlinear dynamics in complex adaptive systems). There

450 is, indeed, an increasing amount of person-oriented methods that can be used (Garcia, 2017ab;

451 Garcia \& Lindskär, 2016; Garcia, MacDonald \& Archer, 2015; Bergman \& Lundh, 2015;

452 Valsiner, 2015; Molenaar, 2015; Laursen, 2015; Asendorpf, 2015; von Eye \& Wiederman, 2015;

453 Aunola, Tolvanen, Kiuru, Kaila, Mullola \& Nurmi, 2015; Baker, 2015; MacDonald \& Kormi-

454 Nouri, 2013) as well as statistical software aimed for these endeavors (ROPstat; Vargha, Torma

$455 \&$ Bergman, 2015).

456 Conclusion and final remarks 
457 One way to improve the applicability -and consequently the usefulness- of a measure is to verify

458 its reliability and validity in different cultural contexts. The present study tested and confirmed

459 the one-dimensionality structure and the reliability of the two scales of the RMQ (i.e., 460 locomotion and assessment) in the Swedish context. Moreover, the present study confirmed the 461 discriminant validity of self-regulation modes on affective well-being dimensions. This is 462 important because the two affectivity dimensions are also measures of anxiety, which involves 463 high negative affect, and depression, which involves both high negative affect and low positive 464 affect (Clark \& Watson, 1991). We suggest that the Swedish version of the RMQ, with only 465 minor modifications, is a useful instrument to tap individual differences in locomotion and 466 assessment. In sum, the present study contributes to the validation of the RMQ in the Swedish 467 culture, adds support to the theoretical framework of self-regulatory mode, and suggests that the 468 regulatory mode system could be a psychological complex adaptive system, that along with the 469 biological affectivity system, forms a larger biopsychosocial system of self-regulation.

\section{References}

471 Amato, C., Baldner, C., Pierro, A., \& Kruglanski, A.W. (2017). “Tempus Divitiae”: Locomotion 472 Orientation and Evaluation of Time as a Precious Resource. Time \& Society, in press.

473 Amato, C., A., Baron, R., Barbieri, B., Bélanger, J. J., \& Pierro, A. (2017). Regulatory Modes 474 and Entrepreneurship: The Mediational Role of Alertness in Small Business Success. 475 Journal of Small Business Management. DOI: 10.1111/jsbm.12255

476 Amato, C., Pierro, A., Chirumbolo, A., \& Pica, G. (2014). Regulatory modes and time 477 management: How locomotors and assessors plan and perceive time. International Journal 478 of Psychology, 49(3), 192-199. 
479 Asendorpf, J. B. (2015). Person-oriented approaches whithin multi-level perspective. Journal of $480 \quad$ Person-Oriented Research, 1 (1-2), 48-55. DOI: 10.17505/jpor.2015.06.

481 Aunola, K., Tolvanen, A., Kiuru, N., Kaila, K., Mullola, S., \& Nurmi, J-E. (2015). A person482 oriented approach to diary data. Children's temperamental negative emotionality increases 483 susceptibility to emotion transmission in father-child dyads. Journal of Person-Oriented 484 Research, 1 (1-2), 72-86. DOI: 10.17505/jpor.2015.08.

485

486

487

488

489

490

491

492

493

494

495

496

497

498

499

500

Avnet, T., \& Higgins, E. T. (2003). Locomotion, assessment, and regulatory fit: Value transfer from "how" to "what". Journal of Experimental Social Psychology, 39(5), 525-530.

Baker, S. M. (2015). Adaptive equilibrium regulation: A balance act in two timescales. Journal of Person-Oriented Research, 1 (1-2), 99-109. DOI: 10.17505/jpor.2015.10.

Benjamin, L., \& Flynn, F. J. (2006). Leadership style and regulatory mode: Value from fit?. Organizational Behavior and Human Decision Processes, 100(2), 216-230. Bergman, L. R., \& Lundh, L-G. (2015). Introduction: The person-oriented approach: Roots and roads to the future. Journal of Person-Oriented Research, 1 (1-2), 1-6. DOI: 10.17505/jpor.2015.01.

Bergman, L. R., \& Magnusson, D. (1997). A person-oriented approach in research on developmental psychopathology. Development and Psychopathology, 9(2), 291-319. DOI: 10.1017/S095457949700206X.

Bergman, L. R., Magnusson, D., \& El-Khouri, B. M. (2003). Studying individual development in an interindividual context: A person-oriented approach. Vol. 4 in the series Paths through life (D. Magnusson, Ed.). Mahwah, NJ: Erlbaum.

Bergman, L. R., \& Wångby, M. (2014). The person-oriented approach: A short theoretical and practical guide. Eesti Haridusteaduste Ajakiri, 2, 29-49. Doi: 10.12697/eha.2014.21.02b. 
501 Bornovalova, M. A., Fishman, S., Strong, D. R., Kruglanski, A. W., \& Lejuez, C. W. (2008).

502 Borderline personality disorder in the context of self-regulation: Understanding symptoms

503 and hallmark features as deficits in locomotion and assessment. Personality and Individual

504 Differences, 44(1), 22-31.

505 Carver, C. S., \& Scheier, M. (1990). Principles of self-regulation: Action and emotion. Guilford 506 Press.

507 Clark, L. A., \& Watson, D. (1991). Tripartite model of anxiety and depression: Psychometric 508 evidence and taxonomic implications. Journal of Abnormal Psychology, 100, 316-336.

509 Cloninger, C. R. (2004). Feeling good: The science of well- being. New York: Oxford University $510 \quad$ Press.

511 Cloninger, C. R., Garcia, D. (2015). The heritability and development of positive affect and 512 emotionality. In: Pluess M, ed. Genetics of psychological well-being-the role of heritability and genetics in positive psychology. New York: Oxford University Press, 97-113.

514 Cloninger, C. R., Svrakic, N. M., \& Svrakic, D. M. (1997). Role of personality self-organization

515 in development of mental order and disorder. Development and Psychopathology, 9, 881516906.

517 Delle Fave, A., \& Bassi, M. (2009). The contribution of diversity to happiness research. The 518 Journal of Positive Psychology, 4, 205-207. DOI 10.1080/17439760902844319.

519 Diener, E. (1984). Subjective well-being. Psycholgical Bullettin, 95, 542-575.

520 Fayolle, A., Kyrö, P., \& Ulijin, J. (2005). The entrepreneurship debate in Europe: A matter of 521 historyand culture? In A. Fayolle, P, Kyrö, and J. Ulijin (Eds.), Entrepreneurship Research 522 in Europe: Outcomes and Perspectives. Cheltenham, UK: Edward Elgar. 
523 Fleming, T.M., Clark, T., Denny, S., Bullen, P., Crengle, S., Peiris-John, R., Robinson, E.,

524 Rossen, F. V., Sheridan, J., \& Lucassen, M. (2013) Stability and Change in the Mental

525 Health of New Zealand Secondary School Students 2007-2012: Results from The

526 National Adolescent Health Surveys. Aust N Z J Psychiatry 1-9.

527 Garcia, D. (2011) Adolescents' happiness: The role of the affective temperament model on

528 memory and apprehension of events, subjective well-being, and psychological well-being.

529 Ph.D. Thesis, University of Gothenburg, Gothenburg.

530 Garcia, D. (2012). The Affective Temperaments: Differences between Adolescents in the Big

531 Five Model and Cloninger's Psychobiological Model of Personality. Journal of Happiness

532 Studies, 13, 999-1017. DOI: 10.1007/s10902-011-9303-5.

533 Garcia, D. (2017a). Affective Profiles Model. In V. Zeigler-Hill \& T. Shackelford (Eds.), 534 Encyclopedia of Personality and Individual Differences (pp. x-x). Cham, Switzerland: 535 Springer. Manuscript in press.

536 Garcia, D. (2017b). Dark Cube. In V. Zeigler-Hill \& T. Shackelford (Eds.), Encyclopedia of 537 Personality and Individual Differences (pp. x-x). Cham, Switzerland: Springer. Manuscript 538 in press.

539 Garcia, D., Adrianson, L., Archer, T., \& Rosenberg, P. (2015). The Dark Side of The Affective 540 Profiles: Differences and Similarities in Psychopathy, Machiavellianism, and Narcissism. $541 \quad$ Sage Open, 5 (4). DOI: 10.1177/2158244015615167.

542 Garcia, D., \& Archer, T. (2016). Empowerment (Character, Motivation, and Regulatory Mode), 543 Positive Affect, and Resilience. The Journal of Happiness and Well-Being, 4, 212-225. 
544 Garcia D, Cloninger KM, Lester N, Cloninger CR. 2017. Self-directedness. In: Zeigler- Hill V,

545 Shackelford T, eds. Encyclopedia of personality and individual differences. Cham: Springer, $546 \quad 1-3$.

547 Garcia, D., Drugge, A., Blixt Samuelsson, H., Storm, U., Archer, T., \& Cloninger, K. M. (2016).

548 The Need of Holistic Interventions in Schools: The Promotion of Healthy and Sustainable 549 Personality Development among Children. Clinical and Experimental Psychology, 2:2. DOI: $550 \quad 10.4172 / 2471-2701.1000129$.

551 Garcia, D., Ghiabi, B., Rosenberg, P., Nima, A. A., \& Archer, T. (2015). Differences between 552 Affective Profiles in Temperament and Character in Salvadorians: The Self-fulfilling 553 Experience as a Function of Agentic (Self-directedness) and Communal (Cooperativeness) 554 Values. International Journal of Happiness and Development, 2, 22-37. DOI: 555 10.1504/IJHD.2015.067592.

556 Garcia, D., Jimmefors, A., Mousavi, F., Adrianson, L., Rosenberg, P., \& Archer, T. (2015). Self557 regulatory Mode (Locomotion and Assessment), Well-Being (Subjective and 558 Psychological), and exercise behavior (Frequency and Intensity) in Relation to High School 559 Pupils’ Academic Achievement. PeerJ, 3, 847. DOI: 10.7717/peerj.847.

560 Garcia D, Lester N, Cloninger KM, Cloninger CR. 2017a. Cooperativeness. In: Zeigler- Hill V, 561 Shackelford T, eds. Encyclopedia of personality and individual differences. Cham: Springer.

562 Garcia D, Lester N, Cloninger KM, Cloninger CR. 2017b. The temperament and character 563 inventory (TCI). In: Zeigler-Hill V, Shackelford T, eds. Encyclopedia of personality and 564 individual differences. Cham: Springer, 1-3. 
565 Garcia, D., \& Lindskär, E. (2016). Regulatory Mode Profiles and the Organization of the Flow of

566 Time. International Journal of School and Cognitive Psychology, 3:3. DOI: 10.4172/2469-

5679837.1000184.

568 Garcia, D., MacDonald, S., \& Archer, T. (2015). Two Different Approaches to The Affective 569 Profiles Model: Median Splits (Variable-Oriented) and Cluster Analysis (Person-Oriented). $570 \quad$ PeerJ, 3:e1380. DOI: 10.7717/peerj.1380.

571 Garcia, D., \& Moradi, S. (2013). The Affective Temperaments and Well-Being: Swedish and 572 Iranian Adolescents' Life Satisfaction and Psychological Well-Being. Journal of Happiness 573 Studies, 14, 689-707. DOI: 10.1007/s10902-012-9349-z.

574 Garcia, D., Nima, A. A., Lindskär, E., Jimmefors, A., Archer, T., MacDonald, S. (2016). 575 Questions of Self-regulation and Affect: Affectivity, Locomotion, Assessment, and 576 Psychological Well-Being. Asian Journal of Health Psychology, 1, 35-48.

577 Garcia, D., Rosenberg, P., Erlandsson, A., \& Siddiqui, A. (2010). On Lions and Adolescents: 578 Affective Temperaments and the Influence of Negative Stimuli on Memory. Journal of 579 Happiness Studies, 11, 477-495. DOI: 10.1007/s10902-009-9153-6.

580 Garcia D, Rosenberg P, Lester N, Cloninger KM, Cloninger CR. 2017. Self- transcendence. In: 581 Zeigler-Hill V, Shackelford T, eds. Encyclopedia of personality and individual differences. 582 Cham: Springer.

583

584 Garcia, D., Rosenberg, P., Lindskär, E., Amato,C., \& Nima, A. A. (2017). The Swedish Version 585 of the Regulatory Mode Questionnaire. Data in Brief, 14, 251-254. DOI: $586 \quad$ 10.1016/j.dib.2017.07.050. 
587 Ghofranipour, F., Saffari, M., Mahmoudi, M., \& Montazeri, A. (2013) Demographical and 588 Psychological Determinants of Depression, Among a Sample of Iranian Male Adolescents. $589 \quad$ Int J Prev Med 4, 1217-1223.

590 Giacomantonio, M., Mannetti, L., \& Pierro, A. (2013) Locomoting toward Well- Being or 591 Getting Entangled in A Material World: Regulatory Modes And Affective Well-Being. $J$ $592 \quad$ EconPsychol, 38, 80-89.

593 Gunderson, J. G., Triebwasser, J., Phillips, K. A., \& Sullivan, C. N. (1999). Personality and 594 vulnerability to affective disorders. In C. R. Cloninger (Ed.), Personality and 595 psychopathology (pp. 3-32). New York: American Psychiatric Publishing.

596 Higgins, E.T., Kruglanski, A.W., \& Pierro, A. (2003). Regulatory Mode: Locomotion and 597 Assessment as Distinct Orientations. In: M. P. Zanna, (Ed.), Advances in Experimental 598 Social Psychology, Academic Press: New York, NY.

599 Hong, R. Y., Tan, M. S., \& Chang, W. C. (2004). Locomotion and assessment: Self-regulation 600 and subjective well-being. Personality and Individual Differences, 37(2), 325-332.

601 Jimmefors, A., Garcia, D., Rosenberg, P., Fariba, M., Adrianson, L., \& Archer, T. (2014). 602 Locomotion (Empowering) and Assessment (Disempowering) Self-regulatory Dimensions 603 as a Function of Affective Profile in High School Students. International Journal of School 604 and Cognitive Psychology, 1, 103. DOI:10.4172/2469-9837.1000103.

605 Kjell, O. N. E., Nima, A. A., Sikström, S., Archer, T., Garcia, D. (2013), Iranian and Swedish 606 adolescents: differences in personality traits and well-being. PeerJ 1:e197; DOI $607 \quad 10.7717 /$ peerj.197.

608 Kline, R.B. (2010). Principles and Practice of Structural Equation Modeling. 3rd edition. New 609 York: Guilford Press. 
610 Kruglanski, A.W., Pierro, A., Higgins, E.T., Capozza, D. 2007. "On the Move" or "Staying Put":

611 Locomotion, Need For Closure And Reactions To Organizational Change. Journal of $612 \quad$ Applied Social Psychology 37(6), 1305-1340 DOI 10.1111/j.1559-1816.2007.00214.x

613 Kruglanski, A. W., Thompson, E. P., Higgins, E. T., Atash, M. N., Pierro, A., Shah, J. Y., \& 614 Spiegel, S. (2000). To "do the right thing" or to "just do it": Locomotion and assessment as 615 distinct self-regulatory imperatives. Journal of Personality and Social Psychology, 79(5), $616 \quad 793-815$.

617 Kruglanski, A.W., Orehek, E., Higgins, E.T., Pierro, A., \& Shalev, I. (2010). Modes of Self618 Regulation: Assessment and Locomotion as Independent Determinants in Goal Pursuit. In R. 619 Hoyle (Ed.). Handbook of personality and self-regulation (pp. 375-402). Hoboken, NJ: 620 Wiley.

621 Larsen, R. J., \& Ketelaar, T. (1991). Personality and susceptibility to positive and negative 622 emotional states. Journal of Personality and Social Psychology, 61, 132-140.

623 Laursen, B. (2015). I don't quite get it..: Personal experiences with the person-centered 624 approach. Journal of Person-Oriented Research, 1 (1-2), 42-47. DOI: $625 \quad 10.17505 /$ jpor.2015.05.

626 Lundh, L-G (2015) The Person as a Focus for Research - The Contributions of Windelband, 627 Stern, Allport, Lamiell, and Magnusson. Journal of Person-Oriented Research, 1 (1-2), 15628 33. DOI: $10.17505 /$ jpor.2015.03.

629 MacDonald S, Kormi-Nouri R (2013) The affective personality, sleep, and autobiographical 630 memories. The Journal of Positive Psychology: dedicated to furthering research and 631 promoting good practice $8,305-313$. 
632 Mannetti, L., Leder, S., Insalata, L., Pierro, A., Higgins, T., \& Kruglanski, A. (2009). Priming 633 the ant or the grasshopper in people's mind: How regulatory mode affects inter-temporal 634 choices. European Journal of Social Psychology, 39(6), 1120-1125.

635 Molenaar, P. C. M. (2015). On the relation between person-oriented and subject-specific 636 approaches. Journal of Person-Oriented Research, 1 (1-2), 34-41. DOI: 637 10.17505/jpor.2015.04.

638 Netemeyer, R. G., Bearden, W. O., \& Sharma, S. (2003), Scaling Procedures: Issues and 639 Applications, Newbury Park, CA: Sage Publications, Inc.

640 Pierro, A., Giacomantonio, M., Pica, G., Krugranski, A. W., \& Higgins, E. T. (2013). 641 Locomotion and the preference for multi-tasking: Implications for well-being. Motivation 642 and Emotion, 37, 213-223. DOI: 10.1007/s11031-012-9300-y.

643 Pierro, A., Leder, S., Mannetti, L., Higgins, E. T., Kruglanski, A. W., \& Aiello, A. (2008). 644 Regulatory mode effects on counterfactual thinking and regret. Journal of Experimental 645 Social Psychology, 44(2), 321-329.

646 Pierro, A., Pica, G., Kruglanski, A. W., \& Higgins, T. E. (2014). Regulatory mode orientations 647 and self-forgiveness. Unpublished manuscript, University of Rome "La Sapienza," Rome, $648 \quad$ Italy.

649 Rapp Ricciardi, M., Åkerman, J., Eerikäinen, P., Ambjörnsson, A., Andersson Arntén, A-C., 650 Archer, T., \& Garcia, D. (2014). Understanding Group and Leader (UGL) Trainers' 651 Personality Characteristics and Affective Profiles. Frontiers in Psychology, 5:1191. DOI: 652 10.3389/fpsyg.2014.01191. 
653 Schmitt, D. P., Long, A. E., McPhearson, A., O’Brien, K., Remmert, B., \& Shah, S. H. (2016).

654 Personality and gender differ- ences in global perspective. International Journal of 655 Psychology. Advance online publication. doi:10.1002/ijop.12265

656 Schütz, E., Archer, T. \& Garcia, D. (2013). Character Profiles and Adolescents' Self-reported 657 Affect. Personality and Individual Differences, 54(7), 841-844. DOI: $658 \quad$ 10.1016/j.paid.2012.12.020.

659 Shalev, I., \& Sulkowski, M. L. (2009). Relations between distinct aspects of self-regulation to 660 symptoms of impulsivity and compulsivity. Personality and Individual Differences, 47(2), $661 \quad 84-88$.

662 Smith, C.A., Haynes, K.N., Lazarus, R.S., \& Pope, L.K. (1993). In search of the "hot" 663 cognitions: attributions, appraisals, and their relation to emotion. Journal of Personality and 664 Social Psychology, 65 (5), 916-929.

665 SNAE. 2009. Försämring av gymnasieelevers kunskaper i matematik och fysik. [Deterioration of 666 high school pupils' knowledge in mathematics and physics]. Available at 667 http://www.skolverket.se/ om-skolverket/press/pressmeddelanden/2009/kraftig-forsamring668 av-gymnasieelevernas-kunskaper- i-matematik-och-fysik-1.91259.

669 SNAE. 2012. Sammanfattning av PISA-undersökning. [Summary of the PISA investigation]. $670 \quad$ Available at http://www.skolverket.se/publikationer?id=3126.

671 Steenkamp, J-B. E. M., \& Burgees, S. (2002). Optimum stimulation level and exploratory 672 consumer behavior in an emerging consumer market. International Journal of Research in 673 Marketing, 19, 131-150. 
674 Sverigesradio (2013). För lite idrott i skolan tycker forskare. [Too little physical education in

675 school according to scientists]. Available

$676 \mathrm{http}: / /$ sverigesradio.se/sida/artikel.aspx?programid=83\& artikel=1188963.

677 Swain, S. D., Weathers, D., \& Niedrich, R. W. (2008). Assessing Three Sources of Misresponse 678 to Reversed Likert Items. Journal of Marketing Research, 45, 116-131.

679 Tabachnick B.G., Fidell, L.S. (2007). Using multivariate statistics (Fifth edition). Boston: 680 Pearson Education, Inc.Tellegen, A. (1993). Folk concepts and psychological concept of 681 personality and personality disorder. Psychological Inquiry, 4, 122-130.

682 Valsiner, J. (2015). From person-oriented to person-centered psychology: Abstracting structures 683 of relationships. Journal of Person-Oriented Research, 1 (1-2), 7-14. DOI: $684 \quad 10.17505 / j p o r .2015 .02$.

685 Vargha, A., Torma, B., Bergman, L. R. (2015). ROPstat: A general statistical package useful for 686 conducting person-oriented analyses. Journal of Person-Oriented Research, 1, 87-97. DOI: 687 10.17505/jpor.2015.09.

688

von Eye, A., \& Wiedermann, W. (2015). General linear models for the analysis of single subject 689 data and for the comparison of individuals. Journal of Person-Oriented Research, 1 (1-2),

690 56-71. DOI: 10.17505/jpor.2015.07.

691 Vazeou-Nieuwenhuis, A., Orehek, E., \& Scheier, M. F. (2017). The meaning of action: Do self692 regulatory processes contribute to a purposeful life?. Personality and Individual Differences, 693 116, 115-122.Cloninger CR (2004) Feeling good: The science of well-being. Oxford 694 University Press, New York, NY.

695 Watson, D., \& Clark, L. A. (1994). The PANAS-X: manual for the positive and negative affect 696 schedule - Expanded form. University of Iowa Press. 
697 Watson, D., Clark, L.A., \& Tellegen A. (1988). Development and validation of brief measures of 698 positive and negative affect: the PANAS scales. Journal of Personality and Social $699 \quad$ Psychology, 54(6), 1063-1070.

700 Wong, N., Rindfleisch, A., \& Burroughs, J. E. (2003). Do Reverse-Worded Items Confound 701 Measures in Cross-Cultural Consumer Research? The Case of the Material Values Scale. 702 Journal of Consumer Research, 30, 72-91. 


\section{Table $\mathbf{1}$ (on next page)}

The Swedish translation of the Regulatory mode questionnaire 
1 Table 1. The Swedish translation of the Regulatory mode questionnaire.

\begin{tabular}{|c|c|c|c|}
\hline $\begin{array}{l}\text { Item } \\
\text { No. }\end{array}$ & English & Swedish & Keywords \\
\hline 1. & $\begin{array}{l}\text { I don't mind doing things even if they involve } \\
\text { extra effort. }\end{array}$ & $\begin{array}{l}\text { Jag har inget emot att göra saker även om det } \\
\text { innebär en extra ansträngning. }\end{array}$ & extra effort \\
\hline $2(\mathrm{R})$ & $\begin{array}{l}\text { I never evaluate my social interactions with others } \\
\text { after they occur. }\end{array}$ & $\begin{array}{l}\text { Jag utvärderar aldrig mina sociala samspel med } \\
\text { andra efter att de hänt. }\end{array}$ & evaluate interactions \\
\hline 3. & I am a "workaholic." & Jag är en "arbetsnarkoman". & workaholic \\
\hline 4. & $\begin{array}{l}\text { I feel excited just before I am about to reach a } \\
\text { goal. }\end{array}$ & $\begin{array}{l}\text { Jag känner mig upprymd precis innan jag uppnår } \\
\text { ett mål. }\end{array}$ & excited \\
\hline 5. & $\begin{array}{l}\text { I enjoy actively doing things, more than just } \\
\text { watching and observing. }\end{array}$ & $\begin{array}{l}\text { Jag tycker bättre om att aktivt göra saker istället } \\
\text { för att bara titta på och observera. }\end{array}$ & actively do things \\
\hline 6. & $\begin{array}{l}\text { I spend a great deal of time taking inventory of } \\
\text { my positive and negative characteristics. }\end{array}$ & $\begin{array}{l}\text { Jag lägger ner mycket tid på att inventera mina } \\
\text { positiva och negativa karaktärsdrag. }\end{array}$ & $\begin{array}{l}\text { inventory of } \\
\text { characteristics } \\
\end{array}$ \\
\hline 7. & I like evaluating other people's plans. & $\begin{array}{l}\text { Jag tycker om att utvärdera andra människors } \\
\text { planer. }\end{array}$ & evaluate others' plans \\
\hline 8. & I am a "doer." & Jag är en människa som får saker och ting gjorda. & doer \\
\hline 9. & I often compare myself with other people. & Jag jämför ofta mig själv med andra. & compare to others \\
\hline 10(R.) & $\begin{array}{l}\text { I don't spend much time thinking about ways } \\
\text { others could improve themselves. }\end{array}$ & $\begin{array}{l}\text { Jag spenderar inte mycket tid på att tänka på hur } \\
\text { andra kan förbättra sig själva. }\end{array}$ & not improve others \\
\hline 11. & I often critique work done by myself and others. & Jag kritiserar ofta mitt och andras arbete. & critique self and others \\
\hline 12. & $\begin{array}{l}\text { I believe one should never engage in leisure } \\
\text { activities. }\end{array}$ & $\begin{array}{l}\text { Jag anser att man aldrig bör engagera sig i } \\
\text { fritidsaktiviteter. }\end{array}$ & \\
\hline 13(R). & $\begin{array}{l}\text { When I finish one project, I often wait awhile } \\
\text { before getting started on a new one. }\end{array}$ & $\begin{array}{l}\text { När jag avslutar ett projekt, väntar jag ofta ett tag } \\
\text { innan jag påbörjar nästa. }\end{array}$ & wait before start \\
\hline 14. & $\begin{array}{l}\text { I have never been late for work or for an } \\
\text { appointment. }\end{array}$ & $\begin{array}{l}\text { Jag har aldrig varit sen till arbetet eller ett avtalat } \\
\text { möte. }\end{array}$ & \\
\hline 15. & I often feel that I am being evaluated by others. & Jag känner ofta att jag blir bedömd av andra. & evaluated by others \\
\hline 16. & $\begin{array}{l}\text { When I decide to do something, I can't wait to get } \\
\text { started. }\end{array}$ & $\begin{array}{l}\text { När jag bestämt mig för att göra något kan jag inte } \\
\text { sätta igång snabbt nog. }\end{array}$ & can't wait \\
\hline 17. & I always make the right decision. & Jag fattar alltid rätt beslut. & \\
\hline 18. & I never find faults with someone I like. & $\begin{array}{l}\text { Jag hittar aldrig några fel på människor jag tycker } \\
\text { om. }\end{array}$ & \\
\hline 19. & I am a critical person. & Jag är en kritisk person. & critical person \\
\hline 20. & $\begin{array}{l}\text { I am very self-critical and self-conscious about } \\
\text { what I am saying. }\end{array}$ & $\begin{array}{l}\text { Jag är väldigt självkritisk och själv-medveten om } \\
\text { vad jag säger. }\end{array}$ & $\begin{array}{l}\text { self-critical and self- } \\
\text { conscious }\end{array}$ \\
\hline 21. & $\begin{array}{l}\text { By the time I accomplish a task, I already have the } \\
\text { next one in mind. }\end{array}$ & $\begin{array}{l}\text { Medans jag slutför ett projekt har jag redan börjat } \\
\text { tänka på nästa. }\end{array}$ & next task in mind \\
\hline 22. & $\begin{array}{l}\text { I often think that other people's choices and } \\
\text { decisions are wrong. }\end{array}$ & $\begin{array}{l}\text { Jag tycker ofta att andra människors val och } \\
\text { beslut är fel. }\end{array}$ & others are wrong \\
\hline 23. & I have never hurt another person's feelings. & Jag har aldrig sårat en annan människas känslor. & \\
\hline $24(\mathrm{R})$ & I am a "low energy" person. & Jag är en människa med låg energi. & low energy \\
\hline 25. & $\begin{array}{l}\text { Most of the time my thoughts are occupied with } \\
\text { the task that I wish to accomplish }\end{array}$ & $\begin{array}{l}\text { För det mesta kretsar mina tankar kring den } \\
\text { uppgift som jag vill slutföra. }\end{array}$ & $\begin{array}{l}\text { thoughts occupied with } \\
\text { tasks }\end{array}$ \\
\hline 26. & $\begin{array}{l}\text { I feel that there is no such thing as an honest } \\
\text { mistake. }\end{array}$ & Jag anser att det inte finns några ärliga misstag. & \\
\hline $27(\mathrm{R})$ & $\begin{array}{l}\text { I rarely analyze the conversations I have had with } \\
\text { others after they occur. }\end{array}$ & $\begin{array}{l}\text { Jag analyserar sällan konversationer jag haft med } \\
\text { andra efter att de inträffat. }\end{array}$ & $\begin{array}{l}\text { rarely analyze } \\
\text { conversations } \\
\end{array}$ \\
\hline 28. & $\begin{array}{l}\text { When I get started on something, I usually } \\
\text { persevere until I finish. }\end{array}$ & $\begin{array}{l}\text { När jag påbörjar något håller jag allt som oftast ut } \\
\text { tills jag slutfört det. }\end{array}$ & persevere until finish \\
\hline 29. & I am a "go-getter." & Jag är en handlingsmänniska. & go-getter \\
\hline 30. & $\begin{array}{l}\text { When I meet a new person I usually evaluate how } \\
\text { well he or she is doing on various dimensions } \\
\text { (e.g., looks, achievements, social status, clothes). }\end{array}$ & $\begin{array}{l}\text { När jag träffar en ny människa bedömer jag oftast } \\
\text { hur han eller hon klarar sig på olika plan (t. ex } \\
\text { utseende, prestationer, social status, kläder). }\end{array}$ & evaluate dimensions \\
\hline
\end{tabular}


2 Note: light grey cells $=$ locomotion items, dark grey cells $=$ assessment items, white cells $=$ lie scale (not used in the 3 present study), and $(\mathrm{R})=$ reversed item. Item 10 was removed from the final analysis due to low loading. Adapted 4 from Garcia, Rosenberg, Lindskär, Amato \& Nima, 2017, with permission from D. Garcia. 
Table 2 (on next page)

Correlations, Cronbach's alpha, Means and SD ( \pm ) for all variables in the study 
1 Table 2. Correlations, Cronbach's alpha, Means and $S D( \pm)$ for all variables in the study.

\begin{tabular}{ccccc}
\hline & & \multicolumn{2}{c}{ Affective Well-Being } & Regulatory Mode \\
\hline \multirow{2}{*}{$\begin{array}{c}\text { Affective Well- } \\
\text { Being }\end{array}$} & Positive Affect & Positive Affect & Negative Affect & Locomotion \\
Self-regulatory & Legative Affect & - & - & \\
Mode & Assessment & $.29^{* *}$ & $-.13^{* *}$ & - \\
& Mean and SD $( \pm)$ & $3.54 \pm 0.64$ & $.40^{* *}$ & $.08^{*}$ \\
& Cronbach's alpha & .85 & $2.21 \pm 0.67$ & $3.96 \pm 0.66$ \\
\end{tabular}

2 Note: ${ }^{*} p<.05 .{ }^{* *} p<.01$. Light grey cells: significant correlations between participants' locomotion and affectivity scores; dark grey

3 cells: significant correlations between participants' assessment and affectivity scores; black cells: significant correlations within self-

4 regulatory modes and affectivity dimensions, respectively. 


\section{Table 3(on next page)}

Standardized and unstandardized structural coefficients for the relationship between self-regulatory modes (locomotion and assessment) and affective well-being (positive affect and negative affect) 
1 Table 3. Standardized and unstandardized structural coefficients for the regression

2 weights/loadings between the Swedish version of the RMQ-scales locomotion and assessment and

3 its respective items $(N=650)$.

\begin{tabular}{lllllc}
\hline Regulatory Mode & Item & $\boldsymbol{\beta}$ & $\boldsymbol{S E}$ & $\boldsymbol{B}$ & $\boldsymbol{P}$ \\
& 1. extra effort. & .55 & .11 & 1.00 & $<.001$ \\
& 3. workaholic & .50 & .11 & 1.07 & $<.001$ \\
& 4. excited & .34 & .08 & 0.61 & $<.001$ \\
& 5. actively doing things & .53 & .09 & 0.96 & $<.001$ \\
& 8. doer & .73 & .11 & 1.31 & $<.001$ \\
& 13(R) wait before start & .29 & .10 & 0.62 & $<.001$ \\
& 16. can't wait & .15 & .09 & 0.29 & $<.001$ \\
& 21. next task in mind & .38 & .10 & 0.82 & $<.001$ \\
& 24(R). low energy & .49 & .11 & 1.08 & $<.001$ \\
& 25. thoughts occupied with task & .32 & .09 & 0.60 & $<.001$ \\
& 28. persevere until finish & .56 & .11 & 1.13 & $<.001$ \\
& 29. go-getter & .72 & .10 & 1.29 & $<.001$ \\
\hline 2(R). evaluate interactions & .26 & .10 & 0.54 & $<.001$ \\
6. inventory of characteristics & .46 & .12 & 0.99 & $<.001$ \\
& 7. evaluate other's plans & .53 & .13 & 1.16 & $<.001$ \\
& 9. compare to others & .55 & .14 & 1.21 & $<.001$ \\
& 11. critique self and others & .63 & .14 & 1.31 & $<.001$ \\
& 15. evaluated by others & .49 & .12 & 1.00 & $<.001$ \\
Assessmetion & .66 & .14 & 1.38 & $<.001$ \\
& 19. critical person & .64 & .13 & 1.23 & $<.001$ \\
20. self-critical and self-conscious & .48 & .11 & 0.92 & $<.001$ \\
& 22. others are wrong & .42 & .12 & 0.91 & $<.001$ \\
& 27(R). rarely analyze conversations & .44 & .11 & 1.00 & $<.001$ \\
30. evaluate dimensions & & &
\end{tabular}

4 
Table 4(on next page)

Standardized and unstandardized structural coefficients for the relationship between self-regulatory modes (locomotion and assessment) and affective well-being (positive and negative affect) $(N=650)$. 
1 Table 4. Standardized and unstandardized structural coefficients for the relationship between self-regulatory modes (locomotion and

2 assessment) and affective well-being (positive affect and negative affect) $(N=650)$.

\begin{tabular}{|c|c|c|c|c|c|}
\hline Predictor & Outcome & $\beta$ & $\mathrm{SE}$ & $B$ & $p$ \\
\hline Locomotion & & .54 & .03 & .53 & $<.001$ \\
\hline Assessment & 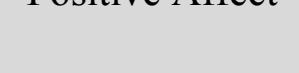 & -.18 & .03 & -.16 & $<.001$ \\
\hline$R^{2}$ & .31 & & & & \\
\hline Locomotion & & -.16 & .04 & -.16 & $<.001$ \\
\hline Assessment & 1) gavive & .41 & .03 & .39 & $<.001$ \\
\hline
\end{tabular}

3 Note: light grey cells: the effect of locomotion on positive affect was stronger than the effect of assessment on positive affect $(Z=-$

4 15.16, $p<.001$ ); dark grey cells: the effect of assessment on negative affect was stronger than the effect of locomotion on negative $5 \operatorname{affect}(Z=10.73, p<.001)$. 


\section{Figure 1}

SEM showing the standardized parameter estimates between the latent factor (i.e., locomotion) and the 12 locomotion items from the RMQ

Note: Chi square $=268.79, d f=54, p<.001 ;$ goodness of fit index $=.93$ and the root mean square error of approximation $=.08(N=650)$. 


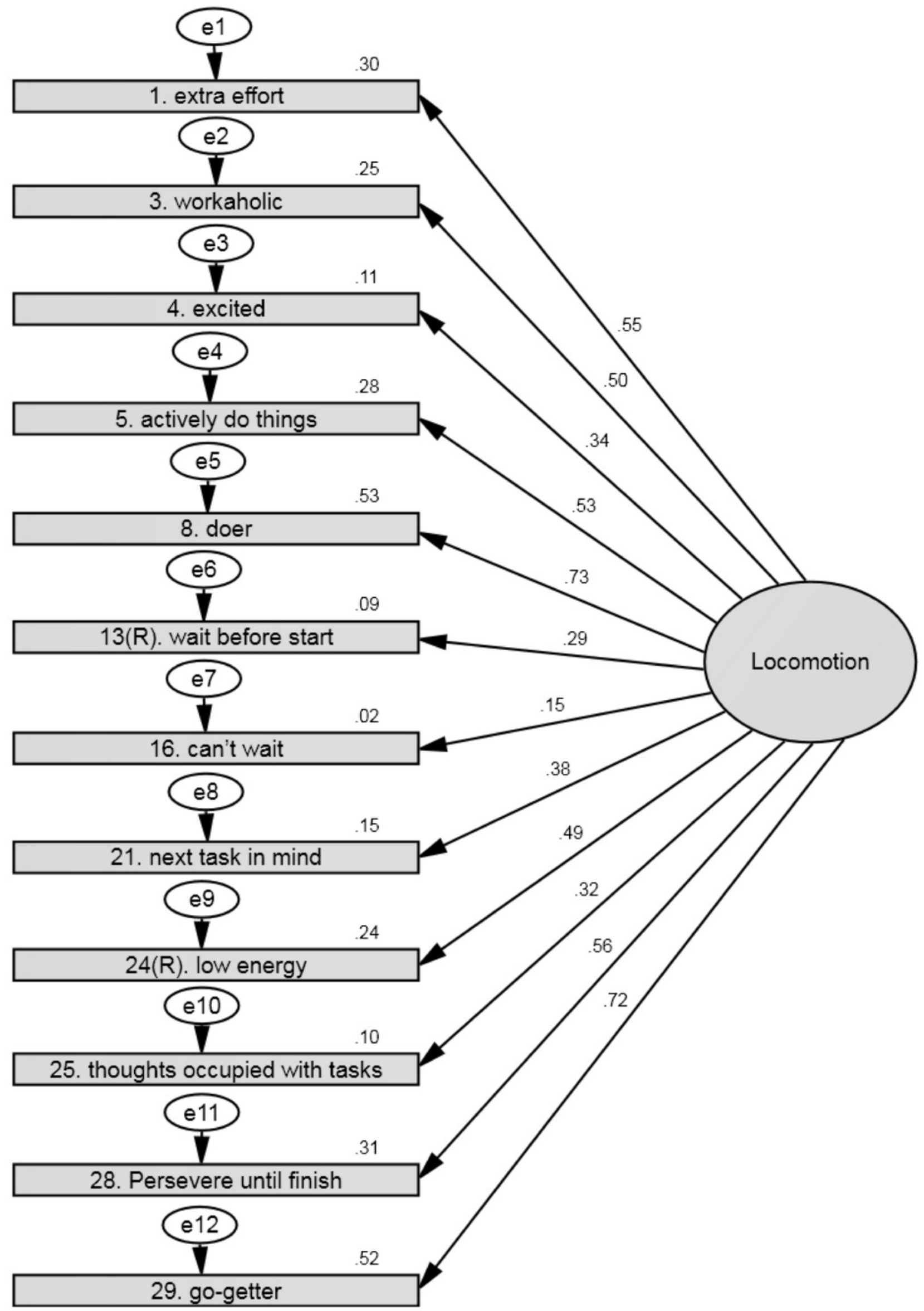


Figure 2

SEM showing the standardized parameter estimates between the latent factor (i.e., assessment) and the 12 assessment items from the RMQ.

Note: Chi square $=362.20, d f=54, p<.001 ;$ goodness of fit index $=.91$ and the root mean square error of approximation $=.09(N=650)$. 


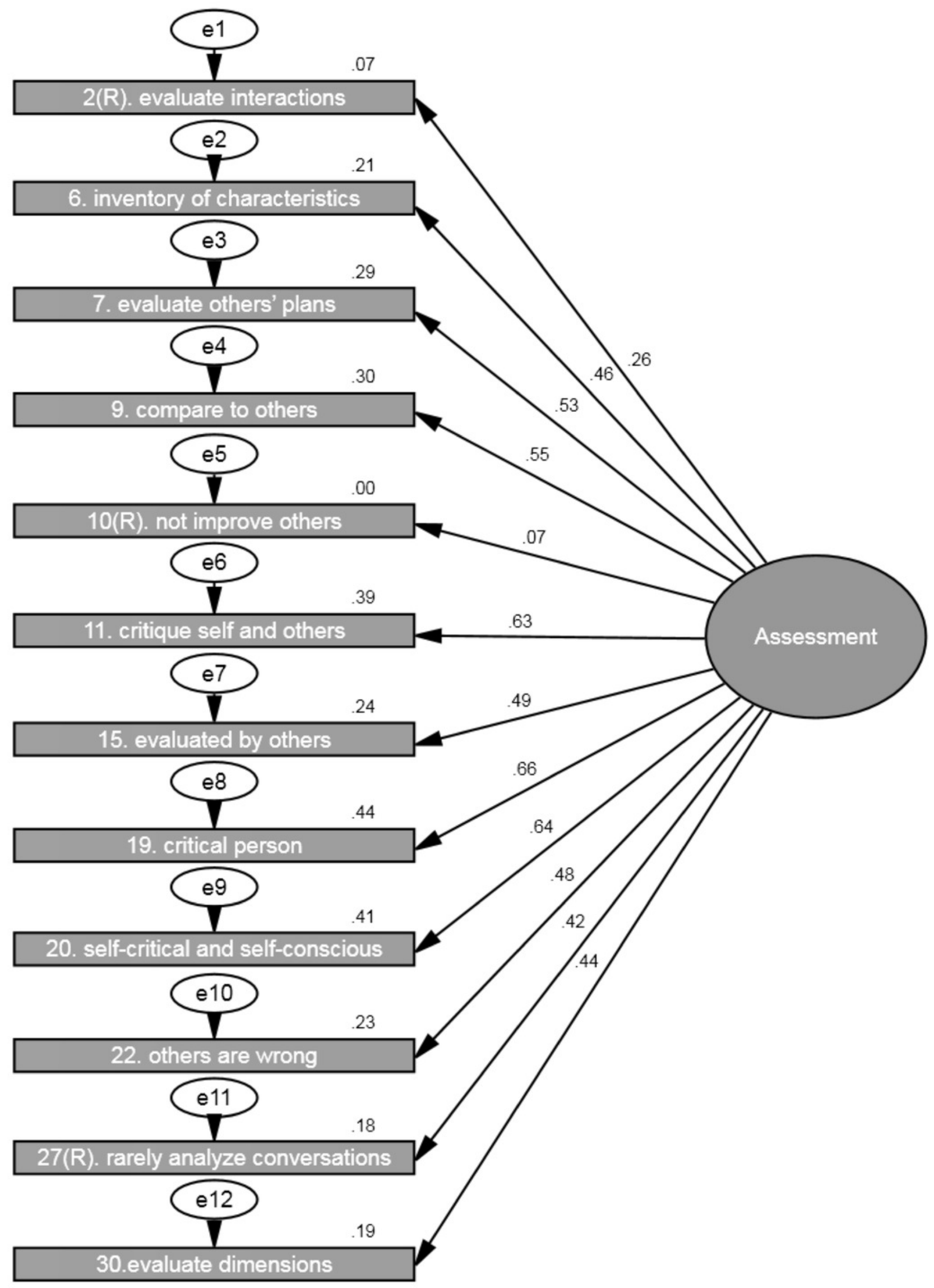

PeerJ reviewing PDF | (2017:04:17634:1:0:NEW 7 Oct 2017) 


\section{Figure 3}

SEM showing the standardized parameter estimates among the latent factor (i.e., assessment) and the 11 assessment items (i.e., without item 10) from the RMQ.

Note: Chi square $=336.88, d f=44, p<.001 ;$ goodness of fit index $=.91$ and the root mean square error of approximation $=.10(N=650)$. 


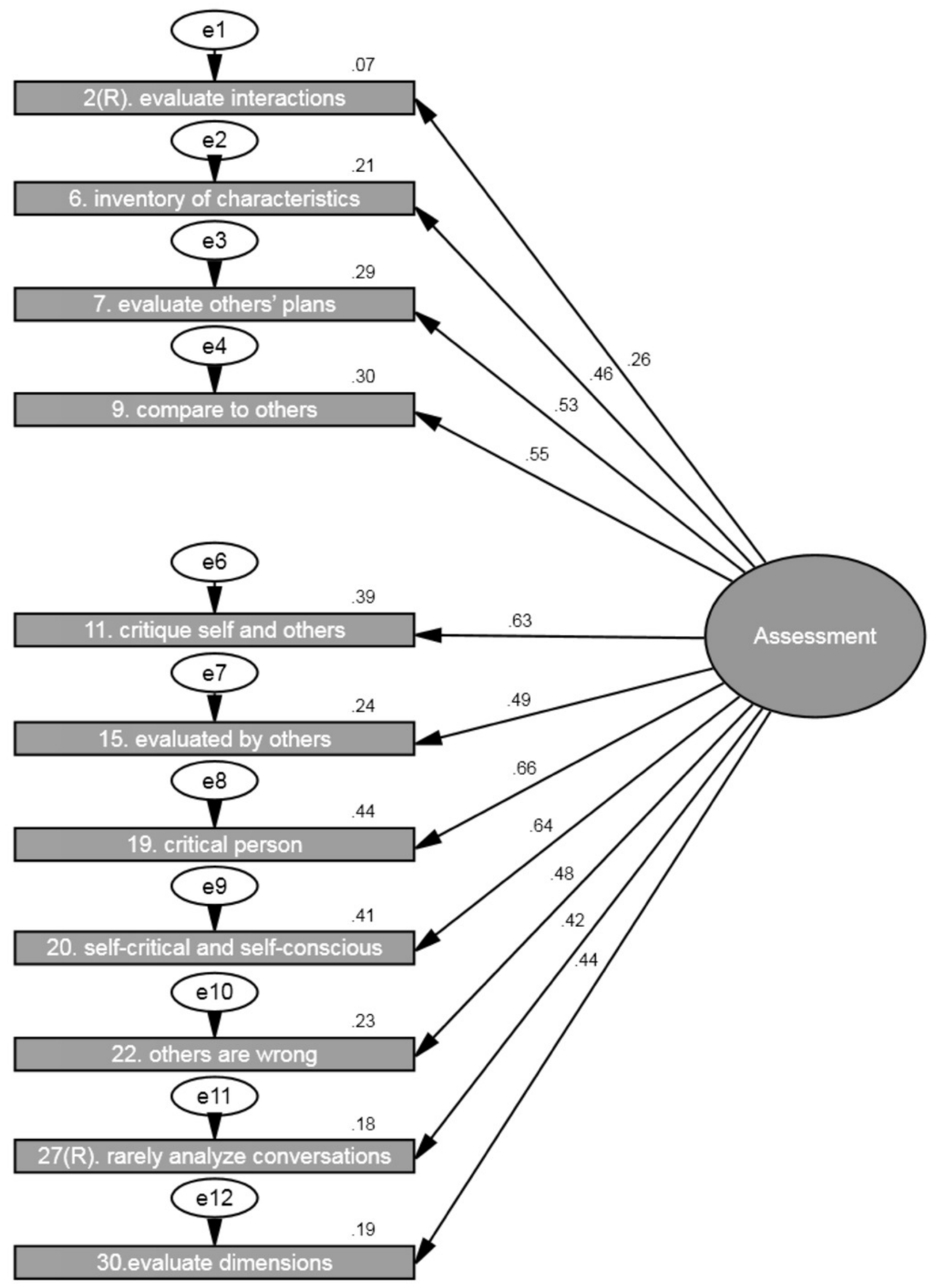

Peer) reviewing PDF | (2017:04:17634:1:0:NEW 7 Oct 2017) 


\section{Figure 4}

SEM showing the standardized parameter estimates for the relationship between selfregulatory modes (locomotion and assessment) and affective well-being (positive affect and negative affect).

Note: Chi square $=27.85, d f=1, p<.001$; goodness of fit index was .98 , comparative fit index $=.93$, incremental fit index $=.93$ and normed fit index $=.93(N=650)$.

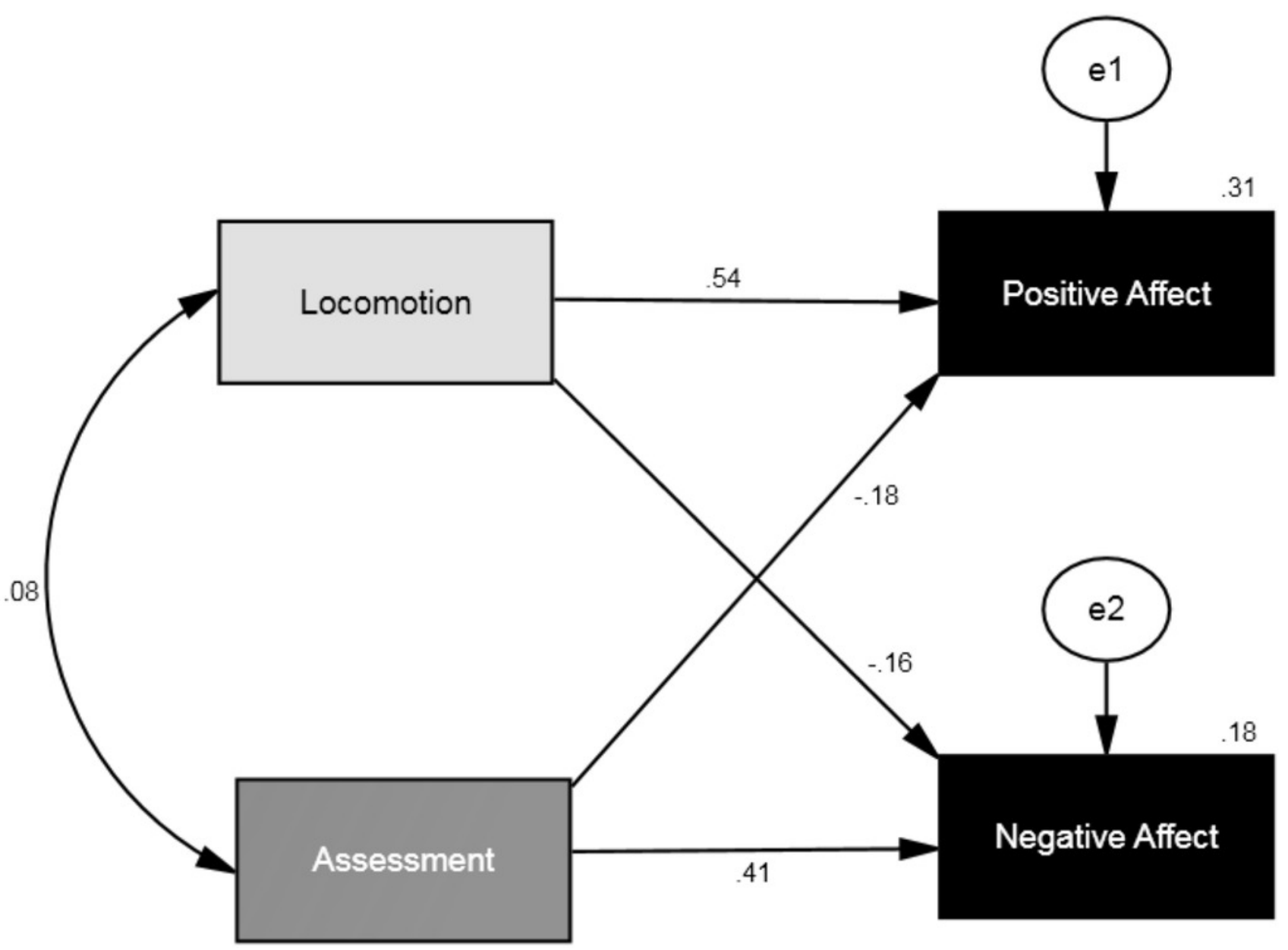

